\title{
MICROMORPHOLOGY OF THE FLORAL ELEMENTS, THE STRUCTURE OF THE NECTARY, AND THE APICULTURAL VALUE OF Elaeagnus commutata BERNH. EX RYDB.
}

\author{
Mirosława Chwil, Elżbieta Weryszko-Chmielewska \\ Department of Botany, University of Life Sciences in Lublin, Akademicka 15, 20-934 Lublin, Poland \\ e-mail: miroslawa.chwil@up.lublin.p
}

Received: 12.10 .2010

\begin{abstract}
The investigations were carried out using light and scanning electron microscopy. The flowers of Elaeagnus commutata grow in clusters of 1-4 in the leaf axils. They are actinomorphic, four-lobed, with a single perianth that is yellow from the adaxial side, while the abaxial side is silvery-white. Peltate hairs of different structure are found on both surfaces of the sepals. The conical epidermal cells of the lobes are covered with a thick striated cuticle. Cylindrical hairs were observed on the edges of the lobes. Peltate hairs also grew on the style. The dish-shaped nectary gland is located at the base of the style. Nectar is secreted through numerous, evenly distributed stomata located above or at the level of other epidermal cells. Different stages of stomatal development are evidence of the asynchronous functioning of the stomata. The nectary consists of small epidermal cells and 5-6 layers of secretory parenchyma. The deeper layers of the gland are composed of larger cells of subglandular parenchyma in which vascular bundles supplying the nectary run. Honey bees were the main pollinators of silverberry. Ten silverberry flowers produced an average of $12 \mathrm{~g}$ of nectar with a sugar concentration in the $29.5-34.5 \%$ range. The weight of pollen produced by 10 flowers was $3.33 \mathrm{mg}$.
\end{abstract}

Key words: Elaeagnus commutata, flower, micromorphology, nectary, nectar secretion, pollen yield

\section{INTRODUCTION}

The genus Elaeagnus of the family Elaeagnaceae comprises about 40 plant species. These are trees or shrubs. In Poland three species are found: autumn olive (Elaeagnus umbellata Thunb.), Russian olive (Elaeagnus angustifolia L.), and silverberry (Elaeagnus commutata Bernh. ex Rydb. syn. E. argentea Pursh) (Szweykowscy, 2003; Seneta and Dolat owski, 2004; Rutkowski, 2006).
E. commutata is native to North America, but it is frequently planted in Europe ( $\mathrm{Heg} \mathrm{i}, 1959)$. This species grows well on dry and sandy nutrientpoor soils with an alkaline $\mathrm{pH}$. It is also tolerant to soil salinity and resistant to drought-induced stress. E. commutata belongs to universal plants used in rehabilitation of degraded areas (S e n e t a and Dolatow ski, 2004).

Silverberry is a plant that is resistant to traffic and industrial smoke pollution, hence it is planted along roads and used in protective plantings around industrial facilities (Seneta and Dolatowski, 2004). $\beta$-carboline alkaloids, which can be a promising source of a $\beta$-carboline drug, have been isolated from the bark of silverberry trees $(\mathrm{Tolkachev}$ et al. 2008). As a melliferous plant, silverberry can supplement forage for insects during the spring period (Kołtows ki, 2006; Li piński, 2010).

Elaeagnus commutata is a thornless shrub, $1.0-3 \mathrm{~m}$ in height and with underground runners (Bugała, 2000; Seneta and Dolatowski, 2004). The leaf blades, $2-10 \mathrm{~cm}$ long, are borne on short stalks (K r ü s s m a n n, 1960; B u g a ł a, 2000). Its young twigs, leaves, and flowers are all covered with silvery peltate hairs ( $\mathrm{S} \mathrm{z}$ w e y k ow s c y, 2003; Seneta and Dolatowski, 2004). Under Polish conditions, this species blooms in May - June. Its flowers release an intense sweet scent and are frequently visited by bees ( $\mathrm{Li}$ p i ń s k i, 2010).

Trees of the genus Elaeagnus can enrich the soil with nutrients as a result of symbiosis with bacteria of the genus Actinomycetes that produce root nodules and fix atmospheric nitrogen $(\mathrm{C}$ a r u et al. 2003; $\mathrm{Cl}$ a w s o n et al. 2004; Khamzina et al. 2009; Folls tad Shah et al. 2010). 
The study of S a s tre et al. (2004) showed that pollen of plants of the genus Elaeagnus exhibited allergenic activity and could sensitize some people. The fruit of silverberry is drupe-like; it is oval and edible (S e neta and Dolatowski, 2004).

The aim of the present study was to investigate the micromorphology of the floral elements and to examine the structure of the nectaries as well as to determine the rate of nectar production and pollen yield of the flowers of Elaeagnus commutata.

\section{MATERIALS AND METHODS}

Flowers at different developmental stages were sampled from silverberry (Elaeagnus commutata Bernh. ex Rydb.) trees growing at Głęboka St. in Lublin. Nectar secreted throughout the lifetime of the flowers was collected using the pipette method ( $\mathrm{J}$ a bło ń s ki , 2003), whereas pollen yield was determined following the method described by $\mathrm{W}$ a r a k o ms k a (1972).

Examination of the flower parts was made under a stereoscopic microscope equipped with a NICON COOLPIX 4500 camera. Their microstructure was observed in a Nikon Eclipse 400 light microscope. The micromorphology of the epidermis covering the surface of the perianth, the pistil, and the floral nectary was observed in a TESCAN VEGA II LMU scanning electron microscope. For stereoscopic microscopy observations, fresh pieces of flowers were sampled at the initial bloom stage.

For scanning electron microscopy examination, the plant material was fixed in $4 \%$ glutaraldehyde and in $0.1 \mathrm{M}$ phosphate buffer with a $\mathrm{pH}$ of 7.0. The fixed plant samples were postfixed in $1 \% \mathrm{OsO}_{4}$ for 1.5 hours, stained in a $0.5 \%$ aqueous solution of uranyl acetate, and dehydrated in alcohol and acetone series. Next, the specimens were critical-point dried in liquid $\mathrm{CO}_{2}$, and coated with gold using an EMITECH K550X sputter coater. The observations of the surface of the perianth, the pistil and the floral nectary were made in a TESCAN VEGA II LMU scanning electron microscope.

\section{RESULTS}

The flowers of Elaeagnus commutata grow on short stalks in clusters of 1-4 in the leaf axils (Fig. $1 \mathrm{~A}, \mathrm{~B})$. Flower diameter is $8-12 \mathrm{~mm}$, whereas perianth length ca. $11 \mathrm{~mm}$. The flowers are actinomorphic, four-lobed, with a single perianth that is fused at the base forming a tube which turns into lanceolate lobes at the apex (Fig. 1C). The perianth is yellow from the adaxial side, while the abaxial surface is silvery-white (Fig. 1D). Four stamens with short free filaments and $6 \mathrm{~mm}$ long anthers are fused to the perianth tube (Fig. 1E, F). The pistil with superior ovary is composed of one carpel. The average height of the ovary is $3 \mathrm{~mm}$, while the length of the style is approx. $7 \mathrm{~mm}$.

SEM observations show that differently structured peltate hairs occur on both surfaces of the sepals. Star-shaped hairs with loosely arranged components are observed on the adaxial side, whereas on the abaxial surface hairs are densely packed and composed of many radially arranged segments that adjoin each other (Fig. 2A, B). The conical epidermal cells have their outer walls covered with a thick striated cuticle that may disperse sunlight (Fig. 2C), which protects the surface of the flower against overheating. The adaxial apical part of the perianth lobes is pubescent with cylindrical hairs (Fig. 3A).

Star-shaped hairs, similar to those found on the adaxial surface of the sepals, were also observed on the style (Figs 2D, E; 3B). The stigma was covered with papillae on witch a milk-coloured secretion was deposited at the receptive stage of the pistil (Fig 2F-H).

The dish-shaped nectary gland, 1.5-2.3 mm in diameter, is located at the base of the style (Figs 1G-I; 3B, C). Numerous, evenly distributed stomata are found in the epidermis of the nectary (Fig. 3E, F). They are arranged in different directions, above or at the level of other epidermal cells. Larger, fully-developed stomata, which secret nectar, occur on small protuberances. Both epidermal and guard cells are covered by a smooth cuticle. The stomata are at different developmental stages. In some of them, the pores are open, while some other are immature and their pores are covered by a cuticle. This is evidence of the asynchronous functioning of the stomata and that only some of them secret nectar.

In the cross-sectional view of the nectary, there can be distinguished small cells in the epidermal layer and 5-6 layers of secretory parenchyma (Fig. 3D). The deeper layers of the gland are composed of larger subglandular parenchyma cells. Vascular bundles supplying the nectary run within this tissue.

Monitoring of flower visitation by insects showed that the main pollinators were honey bees that collected nectar and pollen. 10 silverberry flowers were found to produce an average of $12.0 \mathrm{mg}$ of nectar. Nectar sugar concentration was in the range of 29.5-34.5\% . Average sugar yield was $3.7 \mathrm{mg} / 10$ flowers (Fig. 4).

The weight of pollen produced in 100 stamens of this species, as determined in the present study, ranged between 6.49 and $10.01 \mathrm{mg}$, with an average value of $8.32 \mathrm{mg}$. Pollen weight per 100 flowers was $33.3 \mathrm{mg}$ (Fig. 5). 

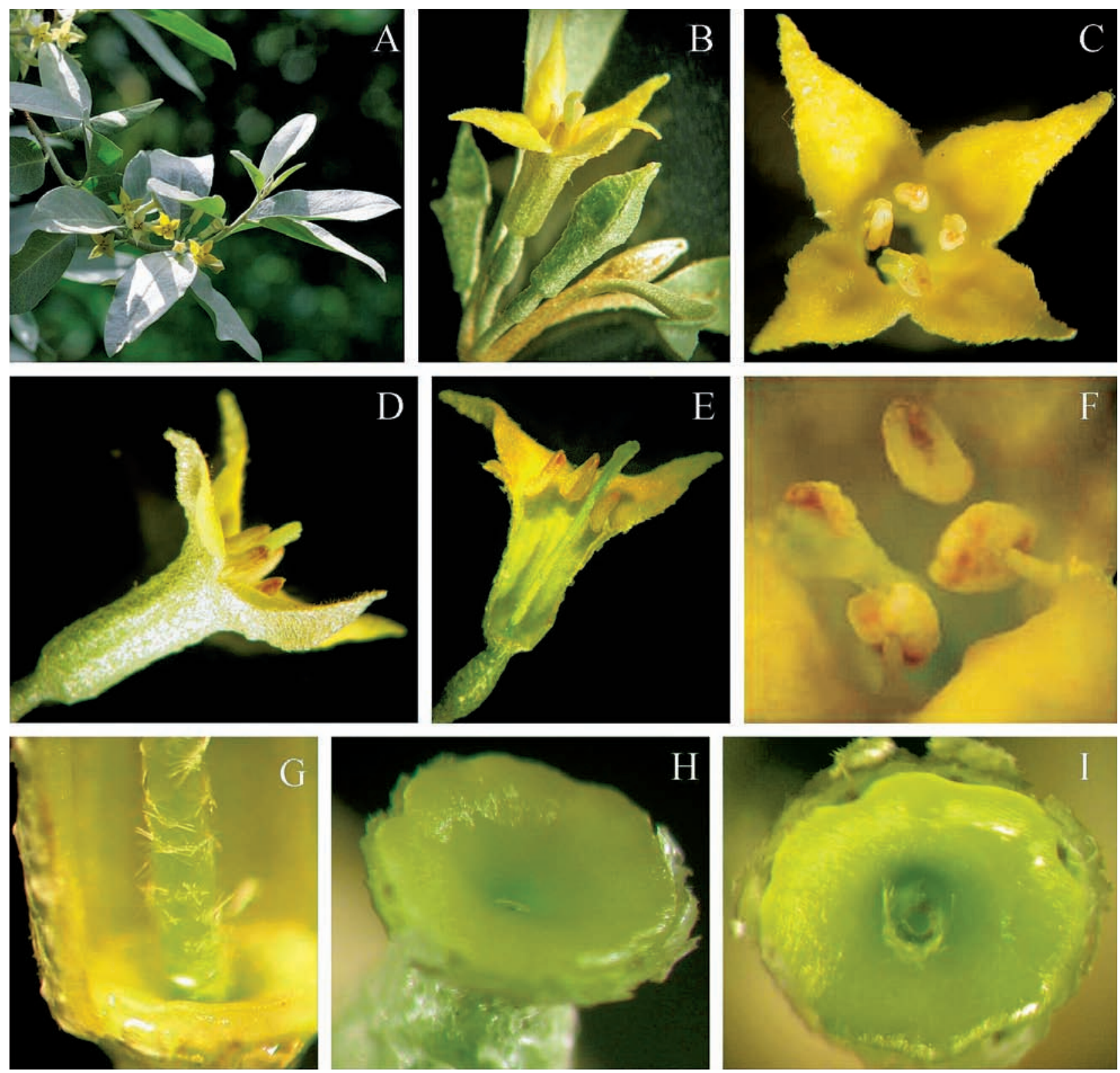

Fig. 1. Elaeagnus commutata flowers and the location of the nectary:

A, B - Flower clusters,

C - A four - lobed flower,

D - The silvery-white abaxial side of the flower,

E - Longitudinal section of the flower,

F - Four stamens with short filaments,

G-I - The dish shaped nectary is located at the base of the style. 

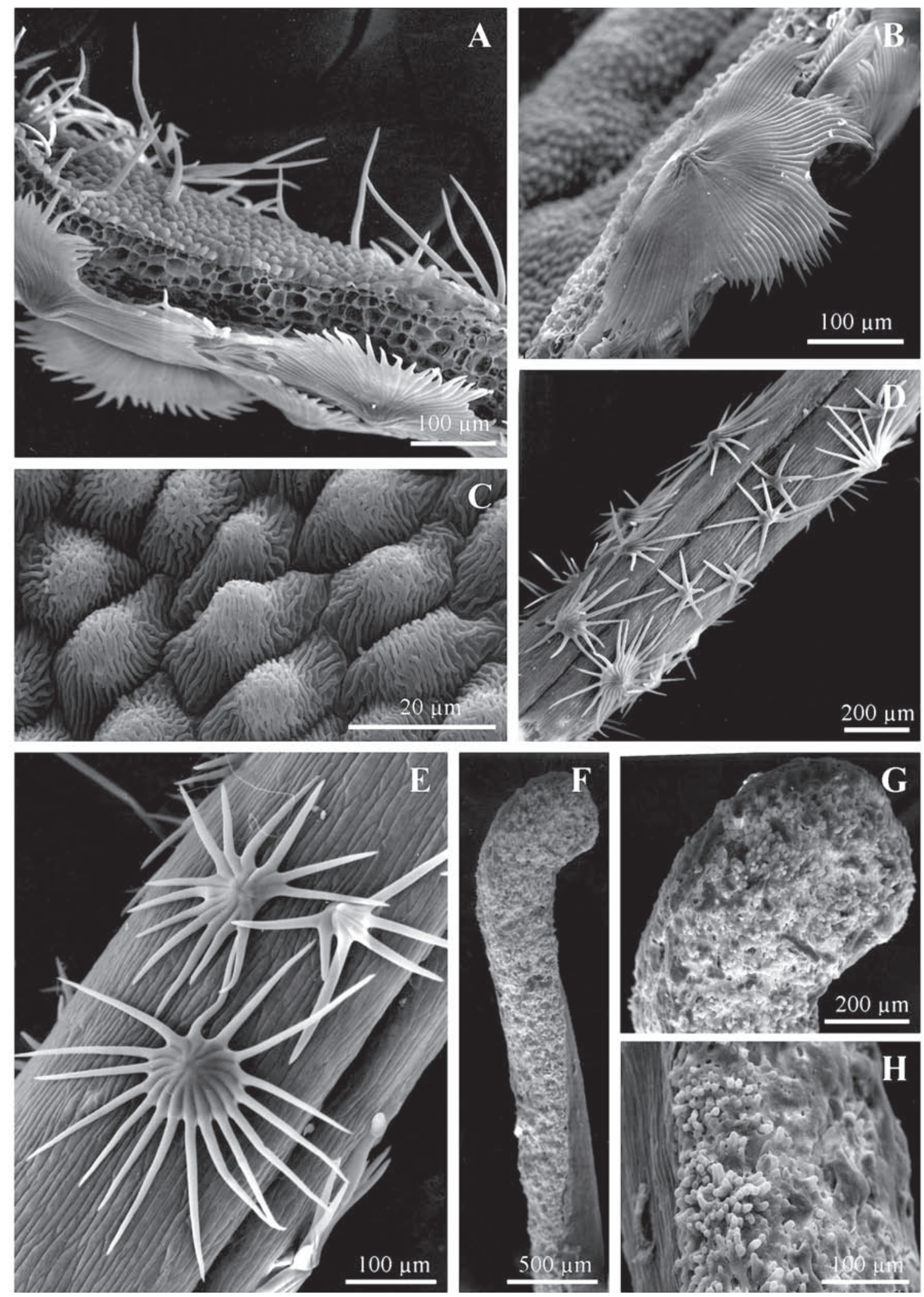

Fig. 2. Filaments sepals and pistil of Elaeagnus commutata:

A - Cross section of the sepal with peltate hairs,

B - Peltate hairs on the leaf edge,

C - Papillae on the adaxial surface of the sepal,

D, E - Star-shaped hairs on the style,

$\mathrm{F}-\mathrm{H}$ - The stigma covered with secretion between the papillae. 

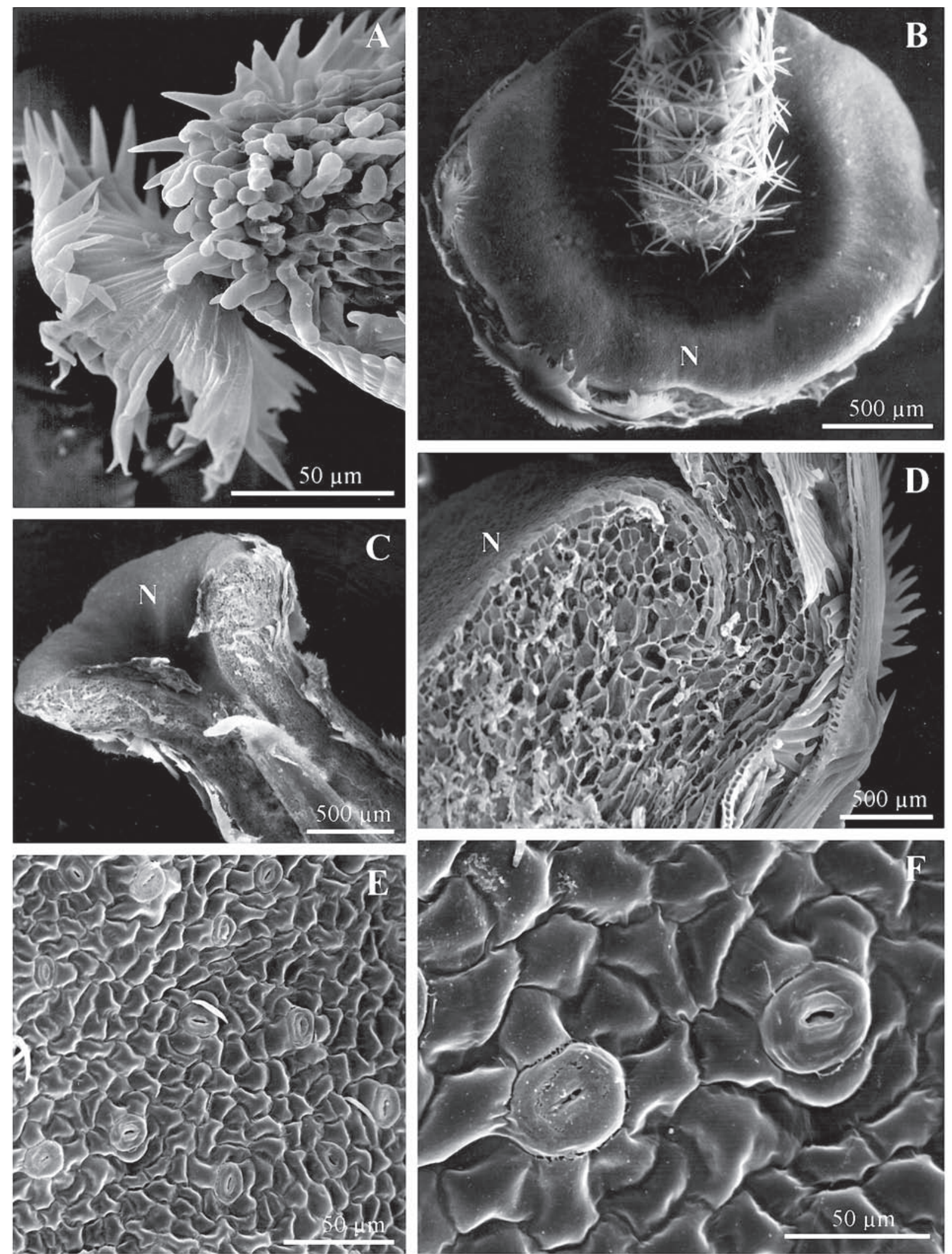

Fig. 3. Part of the sepal and nectary of Elaeagnus commutata:

A - The top of the sepal with peltate and cylindrical hairs,

$\mathrm{B}, \mathrm{C}-$ The nectary $(\mathrm{N})$ at the base of the style,

$\mathrm{D}$ - Longitudinal section of the nectary and perianth,

E-F - The nectary epidermis with stomata. 


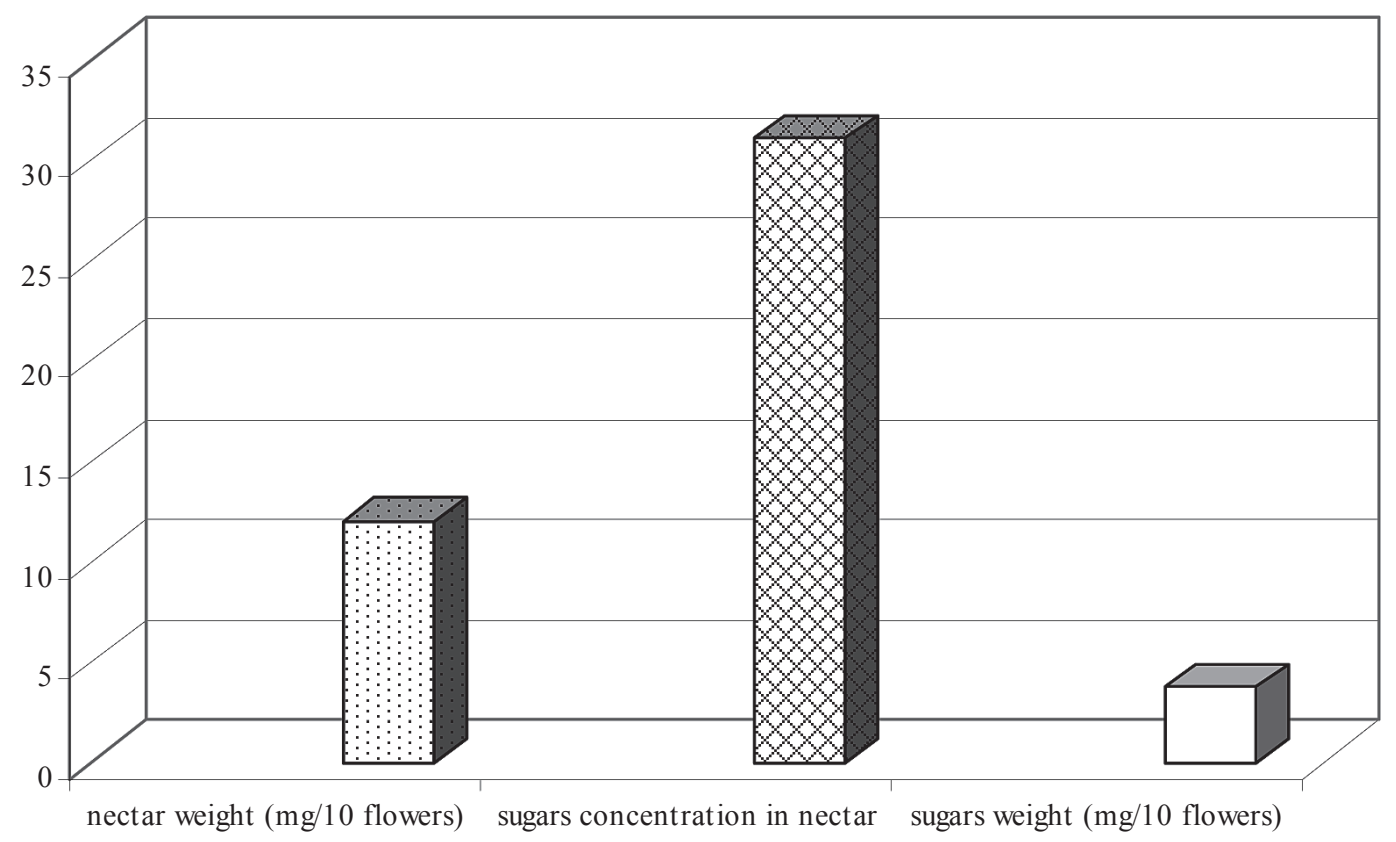

$(\%)$

Fig. 4. The nectar production rate of Elaeagnus commutata flowers

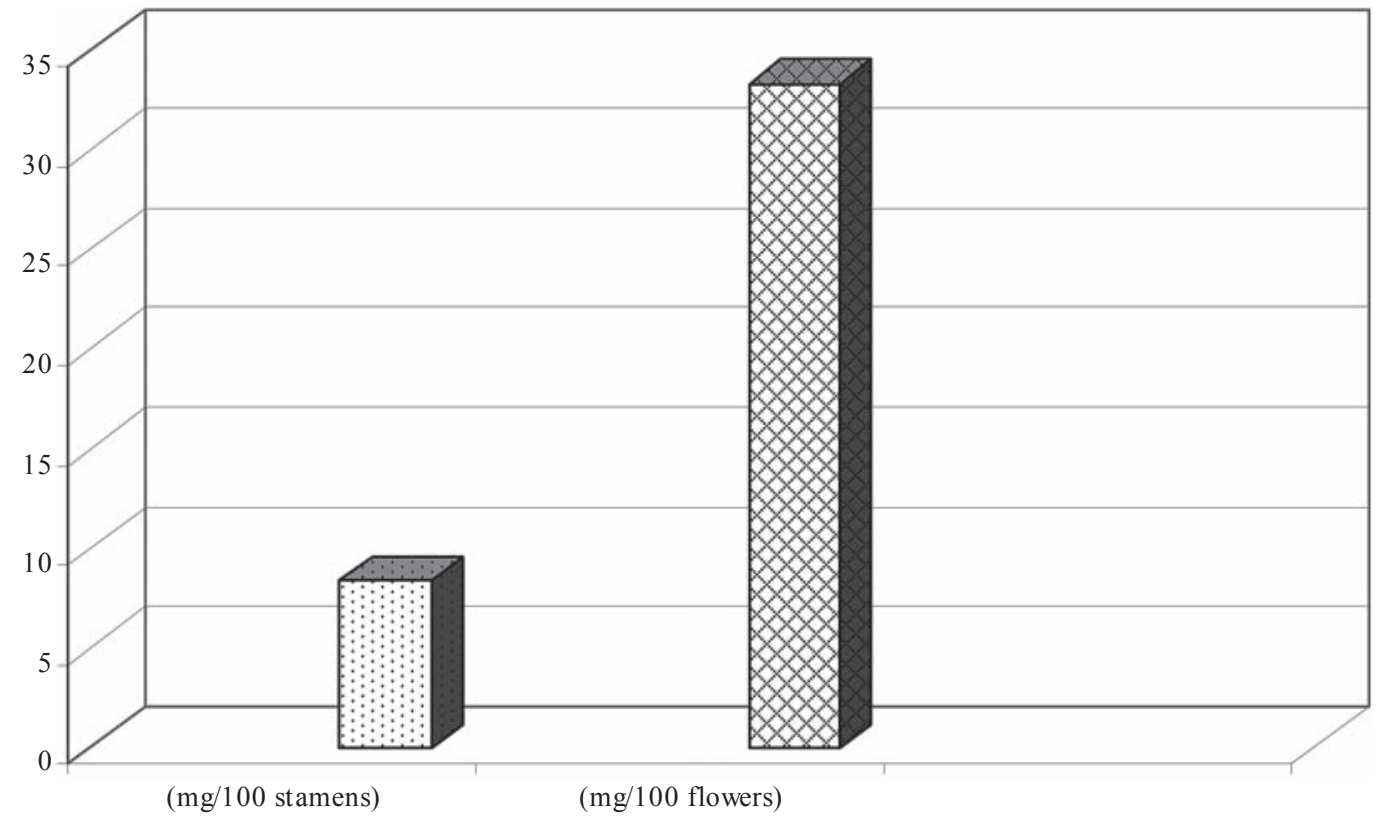

Fig. 5. Pollen field of Elaeagnus commutata

\section{DISCUSSION}

The flowers of Elaeagnus commutata emit an intense sweet scent that probably comes from the conical papillae of the adaxial epidermis of the perianth as well as from the hairs located in the apical portions of the perianth lobes. The presence of essential oils in the epidermal cells of the petals has been found in many plant species (Vogel, 1990; S t p i c z yńs k a, 2001). In addition to the yellow colour of the upper surface of the perianth, the glistening outer part of the perianth also belongs to important visual attractants for insects. The glistening elements in the flowers are particularly important for certain groups of insects, inter alia, for dipterans ( $\mathrm{K} \mathrm{u} \mathrm{g} \mathrm{l} \mathrm{e} \mathrm{r,} \mathrm{1970;} \mathrm{P} \mathrm{r} \mathrm{o} \mathrm{c} \mathrm{t} \mathrm{o} \mathrm{r}$ et al. 1996). The function of the peltate hairs is also to reduce transpiration in the organs covered by them (E s a u , 1970).

The nectary gland of silverberry forms an expanded disc located at the base of the style. Its upper 
surface is slightly depressed, which enables the secreted nectar to accumulate. In accordance with the data reported by B e rnarde 11 o (2007), the hypanthium is the organ on which the nectary is located in the flowers of Elaeagnaceae. The hypanthial nectaries are well-developed in representatives of this family (De Craene and Miller 2004).

In Elaeagnus commutata, different developmental stages were observed in the stomata in the epidermis of the nectary during its activity. This trait indicates asynchronous nectar secretion by the stomata. Variations in the formation of stomata on the nectary surface have also been observed in other plants species, among others, in Eucaliptus (D a v is , 1997), Ocimum (Chwil, 2007), Echium (Chwil and We ry s zk o- Ch mi e lew ska, 2007), Rhododendron catawbiense (Werys zko-Chmielew $\mathrm{ka}$ et al. 2007) and Rhododendron japonicum (Weryszko-Chmielewska and Chwil, 2007), Melisa (C h w i 1, 2009), Erica (W e r y s z k oChmielewska et al. 2009), Malus (Weryszko-Chmielewska and Dmitruk, 2009).

Based on the obtained study results, nectar production in Elaeagnus commulata can be estimated as abundant. Rawski (1948) presents a similar evaluation of the rate of nectar production in this taxon (E. argentea), giving the highest value (3) in the scale presented in his paper. Due to nectar sugar content (ca. $30 \%$ ), sugar yield in E. commutata was approx. $3.7 \mathrm{mg} / 10$ flowers. This value can be considered to be average. But K ołtow ski (2004) reports honey yield of $20 \mathrm{~kg}$ per ha for the species E. angustifolia and estimates this yield to be low.

Pollen reward offered to pollinators by the flowers of E. commutata was $3.33 \mathrm{mg} / 10$ flowers. In the estimation of R aw ski (1948), the weight of pollen produced by the flowers of this species can be included in average values. However, Kołtowski (2006) estimated pollen yield of a related species, E. angustifolia, at $35 \mathrm{~kg}$ per ha.

\section{REFERENCES}

B er narde11o G. 2007. A systematic survey of floral nectaries. In: Nicolson S. W., Nepi M., Pacini E. Nectaries and nectar. Dordrecht, Springer.

Bugała W. 2000. Drzewa i krzewy. Państwowe Wydawnictwo Rolnicze i Leśne, Warszawa (in Polish).

Caru M., Mosquera G., Bravo L., Guevara R., Sepulveda D., Cabello A. 2003. Infectivity and effectivity of Frankia strains from the Rhamnaceae family on different actinorhizal plants. Plant Soil. 251(2): 219-225

Chwil M. 2007. Flowering pattern, the structure of nectary surface and nectar secretion in two varieties of Ocimum basilicum L. Acta Agrobot. 60 (1): 55-65.
Chwil M. 2009. Flowering biology and nectary structure of Melissa officinalis L. Acta Agrobot. 62 (2): 23-30.

Chwil M., Weryszko-Chmielewska E. 2007. Nectary structure and nectar secretion of Echium russicum J. F. Gmel. flowers. Acta Agrobot. 60 (1): 25-33.

Clawson M.L., Bourret A., Bensona D.R. 2004. Assessing the phylogeny of Frankia-actinorhizal plant nitrogen-fixing root nodule symbioses with Frankia 16S rRNA and glutamine synthetase gene sequences. Mol. Phylogenet. Evol. 31: 131-138.

D a v is A.R. 1997. Influence of floral visitation on nectary - sugar composition and nectary surface changes in $\mathrm{Eu}$ calyptus. Apidologie, 28: 27-42.

E s a u K. 1970. Anatomia roślin. Państwowe Wydawnictwo Rolnicze i Leśne, Warszawa (in Polish).

Follstad Shah J.J., Harner M.J., Tibbets T.M. 2010. Elaeagnus_angustifolia_elevates soil inorganic nitrogen pools in riparian ecosystems. Ecosystems. 13(1): 46-61.

Heg i G. 1959. Illustrierte Flora von Mittel-Europa. Mit besonderer Berücksichtigung von Deutschland, Österreich and der Schweiz. Carl Hanser, Verlag, München.

Jabłoń sk i B . 1993. Ogródek pszczelarski. Puławy, Oddział Pszczelnictwa ISK w Puławach (in Polish).

Khamzina A., Lamers J.P.A., Martius Ch., Worbes M., Vlek P.L.G. 2006. Potential of nine multipurpose tree species to reduce saline groundwater tables in the lower Amu Darya River region of Uzbekistan. Agrofor. Syst. 68(2):151-165.

Kołtowski Z., 2006. Wielki atlas roślin miododajnych. Przedsiębiorstwo Wydawnicze Rzeczpospolita SA, Warszawa (in Polish).

Kr üssmann G. 1960. Handbuch der leubgehölze. Paul Parey in Berlin und Hamburg.

Kugler H. 1970. Blütenökologie. Stuttgart: Gustav Fisher Verlag.

Lipiński M., 2010. Pożytki pszczele, zapylanie i miododajność roślin. Państwowe Wydawnictwo Państwowe i Leśne, Warszawa (in Polish).

Proctor M., Yeo P., Lack A. 1996. The natural history of pollination. Collins Publishers, London.

R awski W. 1948. Pożytek pszczeli. Cz. 3. Ex Libris, Warszawa (in Polish).

De Craene L.P., Miller A.G. 2004. Floral development and anatomy of Dirachma socotrana, (Dirachmaceae): a controversial member of the Rosales. Plant Syst. Evol. 249 (1-2): 111-127.

Rutkow sk i L ., 2006. Klucz do oznaczania roślin naczyniowych Polski niżowej. Państwowe Wydawnictwo Naukowe, Warszawa (in Polish).

Sastre J., Lluch-Bernal M., Bustillo A.M.G., Carnes J., Maranon F., Casanovas M., Fernandez-Caldas E. 2004. Allergenicity and cross-reactivity of Russian olive pollen (Eleagnus angustifolia). Allergy. 59(11):1181-1186.

Seneta W., Dolatowski J. 2004. Dendrologia. Państwowe Wydawnictwo Naukowe, Warszawa (in Polish). 
Stpiczyńska M. 2001. Osmophore of the fragrant orchid Gymnadenia conopsea L. Orchidaceae. Acta Soc. Bot. Pol. 70: 96-91.

Szweykowscy A. i J., 2003. Słownik botaniczny. Wiedza Powszechna, Warszawa (in Polish).

Tolkachev O.N., Abizov E.A., Abizova E.V., Mal'tsev S.D. 2008. Photochemical study of the bark some plant sof the Elaeagnaceae family as a natura source of beta-carboline indole alkaloids. Pharm. Chem. J. 42(11): 630-632.

Vogel S. 1990. The role of scent glands in pollination: On the structure and function of osmophores. Amerind, New Delhi, India.

Warakomska Z. 1972. Badania nad wydajnością pyłkową roślin. Pszczeln. Zesz. Nauk. 16, 63-70 (in Polish).

Weryszko-Chmielewska E., Chwil M. 2007. Micromorphology of the epidermis of the floral nectary of Rhododendron japonicum (A. Gray) J. V. Suringar ex E. H. Wilson. Acta Agrobot. 60 (1): 45-53.

Weryszko-Chmielewska E., Chwil M., Michońska M. 2007. Micromorphology of nectaries of Rhododendron catawbiense Michx. at different flower development stages. Acta Agrobot. 60 (2): 15-22.

Weryszko-Chmielewska E., Chwil M., Wróbel M. 2009. The position and structure of the nectary in spring heath (Erica carnea L.) flowers. Acta Agrobot. 62 (2): 13-21.

Weryszko-Chmielewska E., Dmitruk M. 2009. Characteristics of blooming, floral nectaries and nectar of Malus sargentii Rehd. Acta Agrobot. 62(1): 17-25.

\section{Mikromorfologia elementów kwiatowych, struktura nektarnika i wartość pożytkowa Elaeagnus commutata Bernh. ex Rydb.}

\section{Streszczenie}

Badania przeprowadzono przy zastosowaniu mikroskopii świetlnej oraz skaningowej elektronowej. Kwiaty Elaeagnus commutata wyrastają po 1-4 w kątach liści. Są promieniste, czterokrotne z okwiatem pojedynczym, który od strony doosiowej jest żółty, a od strony odosiowej srebrzysto-biały. Na obu powierzchniach elementów okwiatu występują tarczowate włoski o różnej budowie. Stożkowate komórki epidermy latek okwiatu pokryte są grubą, prążkowaną kutykulą. Na brzegach łatek obserwowano walcowate włoski. Na szyjce słupka wyrastały tarczowate włoski. Gruczoł nektarnikowy o miseczkowatym kształcie jest położony u nasady szyjki słupka. Sekrecja nektaru odbywa się przez równomiernie rozmieszczone, liczne aparaty szparkowe położone powyżej lub na poziomie innych komórek epidermy. Różne fazy rozwoju aparatów szparkowych świadczą o niesynchronicznym ich funkcjonowaniu. Nektarnik zbudowany jest z drobnych komórek epidermy i 5-6 pokładów parenchymy wydzielniczej. Głębsze warstwy gruczołu utworzone są z większych komórek parenchymy podgruczołowej, w obrębie której przebiegają wiązki przewodzące zaopatrujące nektarnik. Głównymi zapylaczami kwiatów oliwnika były pszczoły miodne. Dziesięć kwiatów oliwnika wydzielało średnio $12 \mathrm{mg}$ nektaru o koncentracji cukrów zawartej w przedziale 29,5-34,5\%. Natomiast masa pyłku wytworzonego przez 10 kwiatów wynosiła 3,33 mg. 